\title{
К ВОПРОСУ О ПРАВОВОМ СТАТУСЕ ЛИЦА, В ОТНОШЕНИИ КОТОРОГО ВЕДЕТСЯ ПРОИЗВОДСТВО ПО ДЕЛУ ОБ АДМИНИСТРАТИВНОМ ПРАВОНАРУШЕНИИ
}

\begin{abstract}
Аннотация: Изучение административно-процессуального положения участников производства по делам об административных правонарушениях имеет актуальное значение. Обусловлено это целым рядом обстоятельств, одним из которых является тот факт, что для всех отраслей права «правовое положение субъекта права» является одним из ключевых, раскрывающих основные юридические институты. Помимо этого развитие отечественного законодательства об административных правонарушенияххарактеризуется отдельными сложностями и противоречиями. В связи с этим изучение административно-процессуального положения участников производства по делам об административных правонарушениях может выявить целый ряд противоречий, содержащихся в Кодексе Российской Федерации об административных правонарушениях, которые не позволяют достичь всех целей производства по делу об административном правонарушении. Все эти и ряд иных обстоятельств обусловливают необходимость совершенствования норм административного права, определяющих правовое положение участников производства по делам об административных правонарушениях. Методологическую основу статьи составили современные достижения теории познания. В процессе исследования применялись теоретический, общефилософские методы (диалектика, системный метод, анализ, синтез, аналогия, дедукиия, наблюдение, моделирование), традиционно правовые методы (формально-логический), а также методы, используемые в конкретно-сочиологических исследованиях (статистические, экспертные оценки и др.). Вопрос о субъектах отрасли права относится к числу наиболее важных и сложных в юридической науке. Его правильное решение влияет на предмет и метод правового регулирования, четкое определение адресатов правовых норм, объема их прав и обязанностей, пределов действия правовых норм отрасли и ее принципов. Исследования, посвященные субъектам административного права, способствуют выработке рекомендаций для законодательной и правоприменительной деятельности, они также необходимы для организации научной работы ученых-административистов.
\end{abstract}

Ключевые слова: статус, положение, права, обязанности, ответственность, гарантии, регулирование, принуждение, санкция, воздействие.

$\mathrm{P}$ аскрытие содержания аминистративно-процессуального положения участников производства по делам об административных правонарушениях показывает, что проблема обеспечения прав и законных интересов личности в производстве по делам об административных правонарушениях имеет несколько основных аспектов в отношении: производства по делам об административных правонарушениях, применения мер административного принуждения в целом, деятельности государства по обеспечению прав и законных интересов физических и юридических лиц в административно-правовой сфере.

Вопрос о субъектах отрасли права относится к числу наиболее важных и сложных в юридической науке. Его правильное решение влияет на предмет и метод правового регулирования, четкое определение адресатов правовых норм, объема их прав и обязанностей, пределов действия правовых норм отрасли и ее принципов. Исследования, посвященные субъектам административного права, способствуют выработке рекомендаций для законодательной и правоприменительной деятельности, они также необходимы для организации научной работы ученых-административистов ${ }^{1}$.

Лицо, в отношении которого ведется производство по делу об административном правонарушении занимает одно из центральных мест в производстве по делу об административном правонарушении, так как само производство непосредственно направлено на своевременное, всестороннее, полное и объективное выяснение вопроса о виновности данного лица в совершении административного правонарушения. Такое лицо обычно занимает позицию активной защиты в

1 См.: Якимов А.Ю. Статус субъекта права (теоретические вопросы) // Государство и право. - 2003. - № 4. - С. 5. 
производстве и, используя предоставленные ему законом процессуальные права, прилагает усилия, чтобы противостоять выдвинутому против него обвинению².

Согласно Кодексу РФ об административных правонарушениях административной ответственности подлежит лицо, достигшее к моменту совершения административного правонарушения возраста шестнадцати лет; не подлежит административной ответственности физическое лицо, которое во время совершения противоправных действий (бездействия) находилось в состоянии невменяемости, то есть не могло осознавать фактический характер и противоправность своих действий (бездействия) либо руководить ими вследствие хронического психического расстройства, временного психического расстройства, слабоумия или иного болезненного состояния психики (ст. 2.3, 2.8 КоАП России). Это основные требования, предъявляемые к данному участнику производства по делу об административном правонарушении.

H.C. Малеин по этому поводу отметил, что закон признает ответственными субъектами правонарушений дееспособных и вменяемых, то есть всех лиц, достигших определенного возраста и обладающих полноценной психикой. Малолетние и психически больные не обладают необходимым сознанием и волей, чтобы адекватно оценивать и разрешать жизненные ситуации: дети вследствие недостаточного психического и физического развития, а душевнобольные - вследствие патологического развития (слабоумия) или деградации сознания (душевная болезнь) ${ }^{3}$.

Специальные признаки можно поделить на группы, отражающие: особенности труда, служебного положения; прошлое противоправное поведение; иные особенности правового статуса граждан (военнообязанный, иностранный гражданин, лицо без гражданства и др. $)^{4}$. Высказывается мнение о том, что для отдельных категорий лиц особенности правового положения обусловливают дополнительные основания для административной

\footnotetext{
2 См.: Дядькин О.Н. Правовой статус лица, привлекаемого к административной ответственности (по материалам административной практики органов внутренних дел): Дис. ... канд. юрид. наук. - М., 2001. - С. 13.

3 См.: Малеин Н.С. Правонарушение: понятие, причины, ответственность. - М., 1985. - С. 19.

4 См.: Бахрах Д.Н. Административная ответственность. M., 1999. - C. 37.
}

ответственности, для других - ограничения применения ее мер 5 .

Как уже отмечалось, права и обязанности граждан в сфере административного права в основном производны от конституционных и конкретизируются во многих законах и подзаконных актах. Содержание административно-правового статуса человека и гражданина, по мнению ряда ученых, составляют:

a) комплекс их прав и обязанностей, закрепленных нормами административного права;

б) гарантии реализации этих прав и обязанностей, включая их охрану законом и механизм защиты органами государства и местного самоуправления.

А.П. Коренев считает, что конституционные положения являются исходными для административноправового статуса граждан, который определяется нормами конституционного, административного и других отраслей права путем предоставления гражданам прав, свобод, а также возложения на них обязанностей в сфере управления и установления ответственности перед государством ${ }^{6}$.

Таким образом, основные права, свободы и обязанности граждан определены Конституцией России, конституциями республик в составе России, Федеральным законом «0 гражданстве Российской Федерации», законами о гражданстве республик в составе Российской Федерации. Данные права, свободы и обязанности непосредственно конкретизированы и содержатся в административном и ином отраслевом законодательстве.

Из сказанного можно сделать вывод о том, что административно-правовой статус гражданина представляет собой закрепленную в законе систему прав и обязанностей, регулирующую взаимоотношения между органами исполнительной власти и гражданином (личностью).

Статус лица, в отношении которого ведется производство по делу об административном правонарушении, является производным от административно-правового статуса личности. Соответственно правовой статус данного лица можно определить как закрепленную в законе систему прав и обязанностей, регулирующую взаимоотношения между полномочным органом (должностным лицом) и лицом, совершившим административное правонарушение.

\footnotetext{
См.: Алехин А.П., Козлов Ю.М. Административное право Российской Федерации. Ч 1. - М., 1994. - С. 229.

6 См.: Коренев А.П. Административное право России. Ч.1. - М., 2002. - C. 67.
} 
Поэтому логичным представляется суждение о том, что в содержание правового положения конкретного индивидуума, привлекаемого к административной ответственности, «входят те субъективные права и обязанности, которые возникают из разнообразных конкретных правоотношений и вследствие этого не являются постоянными».

Следует также отметить, что статус лица, привлекаемого к административной ответственности, является составной частью специального правового статуса граждан, поскольку факт обоснованного подозрения в совершении административного правонарушения, за которое лицо несет административную ответственность, служит основанием для изменения субъективных прав и обязанностей данной категории лиц. Административно-правовой статус гражданина (личности) характеризуется наличием тех же элементов, которые определяют его общий правовой статус в обществе (права, обязанности, ответственность).

Последний названный элемент статуса — ответственность. Она рассматривается в качестве негативной государственной оценки правонарушения, которая характеризуется осуждением правонарушения и его субъекта, наличием неблагоприятных последствий в виде конкретных мер государственного принуждения. Ответственность наступает за нарушение установленных правовыми нормами запретов или за неисполнение или ненадлежащее исполнение возложенных обязанностей.

На лицо, в отношении которого ведется производство по делу об административном правонарушении, как участника производства по делу об административном правонарушении возлагаются процессуальные обязанности. Их неисполнение может влечь за собой применение процессуальных мер обеспечения, например привод в случае неявки лица на рассмотрение дела с его обязательным участием (ст. 27.15 КоАП России), а не наложение административного наказания.

При наделении лица, в отношении которого ведется производство по делу об административном правонарушении, определенными правами и возложении на него обязанностей, необходимо помнить, что в производстве по делам об административных правонарушениях затрагивается ряд конституционных прав личности. К ним, на наш взгляд, относятся следующие: человеческое до-

См.: Мельников В.А. Право лица, привлекаемого к административной ответственности, на защиту: Автореф. дис. ... канд. юрид. наук. - М., 1995. - С. 20. стоинство, личная неприкосновенность, личная и семейная тайна, защита своей чести и доброго имени, неприкосновенность жилища, свободный выбор языка общения, право свободно передвигаться, выбирать место пребывания и жительства, свобода совести и вероисповедания.

Так, согласно статье 21 Конституции Российской Федерации каждый имеет право на свободу и личную неприкосновенность. Поэтому арест, заключение под стражу и содержание под стражей допускаются только по судебному решению. До судебного решения лицо не может быть подвергнуто задержанию на срок более 48 часов. Также необходимо отметить, что без согласия лица не допускаются сбор, хранение, использование и распространение информации о его частной жизни. Право на неприкосновенность частной и семейной жизни и сохранение ее тайны означает предоставленную человеку и гарантированную государством возможность контролировать информацию о самом себе, препятствовать разглашению сведений личного, интимного характера ${ }^{8}$.

Лицо, привлекаемое к любому виду юридической ответственности, вправе знать, в чем оно обвиняется, оспаривать обвинение, заявлять ходатайства и отводы, предоставлять доказательства, обжаловать действия государственных органов и должностных лиц. Лицам, привлекаемым к административной ответственности, предоставлен широкий объем процессуальных прав, гарантированных Конституцией России, законами и подзаконными актами Российской Федерации, и позволяющих активно осуществлять процессуальные действия, отстаивать свою позицию в деле об административном правонарушении.

При этом нельзя представить права субъекта без корреспондирующих обязанностей на другом, образно выражаясь, полюсе правоотношений. М.Я. Масленников по этому поводу отмечает, что применяемые в административно-юрисдикционном процессе нормы формулируются как права для одних участников разбирательства по делам и как обязанности - для других 9 .

Так, право лица, в отношении которого ведется производство по делу об административном правонарушении, давать объяснения и участвовать при рассмотрении дела - это в то же время и обя-

\footnotetext{
8 См.: Воеводин Л.Д. Юридический статус личности в России. - М., 1997. - С. 199.

9 См.: Масленников М.Я. Производство по делам об административных правонарушениях в органах милиции. Тверь, 1992. С. 32.
} 
занности субъекта правоприменения обеспечить названному лицу реализацию соответствующих возможностей. Следует отметить, что на данный момент проблема правового статуса привлекаемого к административной ответственности лица исследована недостаточно глубоко ${ }^{10}$. Между тем в настоящее время необходим такой механизм правового регулирования общественных отношений в сфере деятельности субъекта юрисдикции, при котором личность будет ограждена от необоснованных применений мер административного принуждения и ей будет обеспечена возможность в полной мере реализовать свои права и законные интересы в случае совершения административного правонарушения.

Еще до составления протокола о правонарушении подозреваемый вправе знать, в совершении какого административного правонарушения он подозревается, свои права и обязанности, а также основания и мотивы применения мер обеспечения производства по делу (доставления, личного досмотра, изъятия вещей и документов, медицинского освидетельствования и др.).
Кроме этого, ему должна быть дана возможность осуществлять активные действия (представлять доказательства, давать объяснения и др.).

В соответствии со ст. 25.1 КоАП России лицо, в отношении которого ведется производство по делу об административном правонарушении, вправе знакомиться со всеми материалами дела, давать объяснения, представлять доказательства, заявлять ходатайства и отводы, пользоваться юридической помощью защитника, а также иными процессуальными правами, предусмотренными КоАП России. Дело об административном правонарушении рассматривается с участием лица, в отношении которого ведется производство по делу об административном правонарушении.

В отсутствие указанного лица дело может быть рассмотрено лишь в случаях, если имеются данные о надлежащем извещении лица о месте и времени рассмотрения дела и если от лица не поступило ходатайство об отложении рассмотрения дела, либо если такое ходатайство оставлено без удовлетворения.

\section{Библиография:}

1. Алехин А.П., Козлов Ю.М. Административное право Российской Федерации. Ч 1. - М., 1994.

2. Астахов Д.В., Костенников М.В., Куракин А.В. Административно-процессуальный статус участников производства по делам об административных правонарушениях. - Домодедово, ВИПК МВД России, 2006.

3. Бахрах Д.Н. Административная ответственность. - М., 1999.

4. Воеводин Л.Д. Юридический статус личности в России. - М., 1997.

5. Дядькин О.Н. Правовой статус лица, привлекаемого к административной ответственности (по материалам административной практики органов внутренних дел): Дис. ... канд. юрид. наук. — М., 2001.

6. Коренев А.П. Административное право России. Ч.1. - М., 2002.

7. Малеин Н.С. Правонарушение: понятие, причины, ответственность. - М., 1985.

8. Мельников В.А. Право лица, привлекаемого к административной ответственности, на защиту: Автореф. дис. ... канд. юрид. наук. - М., 1995.

9. Масленников М.Я. Производство по делам об административных правонарушениях в органах милиции. - Тверь, 1992.

10. Якимов А.Ю. Статус субъекта права (теоретические вопросы) // Государство и право. - 2003. — № 4.

11. Куракин А.В. Компетенция полиции в сфере реализации законодательства об административных правонарушениях // NB: Административное право и практика администрирования. - 2013. - 4. C. 28-48. DOI: 10.7256/2306-9945.2013.4.8841. URL: http://www.e-notabene.ru/al/article_8841.html

12. Куракин А.В., Бадулин А.Д., Трегубова Е.В. Административная ответственность за правонарушения на рынке алкоголя и роль полиции в ее реализации // NB: Административное право и практика администрирования. - 2013. - 10. - C. 28-74. DOI: 10.7256/2306-9945.2013.10.10151. URL: http://www.enotabene.ru/al/article_10151.html

13. Костенников М.В., Куракин А.В., Трегубова Е.В. Конституционное право на проведение мирных собраний, митингов, демонстраций, шествий и пикетирования и административная ответственность как средство его обеспечения // NB: Административное право и практика администрирования. - 2013. - 8. C. 82-105. DOI: 10.7256/2306-9945.2013.8.9955. URL: http://www.e-notabene.ru/al/article_9955.html

10 См.: Дядькин О.Н. Указ. раб. - С. 47. 
14. Серов А.С. Административно-правовое положение адвоката в производстве по делам об административных правонарушениях // Полицейская деятельность. - 2013. - 5. - С. 307-311. DOI: $10.7256 / 2222-1964.2013 .5 .10220$.

15. Серов А.С. Статус субъекта права и его реализация в производстве по делам об административных правонарушениях // Полицейская деятельность. - 2013. - 6. - C. 413-421. DOI: 10.7256/22221964.2013.6.10433.

16. Костенников М.В., Куракин А.В., Трегубова Е.В. Конституционное право на проведение мирных собраний, митингов, демонстраций, шествий и пикетирования и административная ответственность как средство его обеспечения // NB: Административное право и практика администрирования. - 2013. 8. - C. 82-105. DOI: 10.7256/2306-9945.2013.8.9955. URL: http://www.e-notabene.ru/al/article_9955.html

17. Трегубова Е.В. Дозволение и запрет в административном праве // NB: Административное право и практика администрирования. - 2013. - 8. - C. 25 - 56. DOI: 10.7256/2306-9945.2013.8.9953. URL: http://www.e-notabene.ru/al/article_9953.html

18. Е.В. Трегубова Запрещающие нормы административного права. // Административное и муниципальное право. - 2011. - 1. - С. $52-55$.

\section{References:}

1. Alekhin A.P., Kozlov Yu.M. Administrativnoe pravo Rossiiskoi Federatsii. Ch 1. - M., 1994.

2. Astakhov D.V., Kostennikov M.V., Kurakin A.V. Administrativno-protsessual'nyi status uchastnikov proizvodstva po delam ob administrativnykh pravonarusheniyakh. — Domodedovo, VIPK MVD Rossii, 2006.

3. Bakhrakh D.N. Administrativnaya otvetstvennost'. - M., 1999.

4. Voevodin L.D. Yuridicheskii status lichnosti v Rossii. - M., 1997.

5. Dyad'kin O.N. Pravovoi status litsa, privlekaemogo $\mathrm{k}$ administrativnoi otvetstvennosti (po materialam administrativnoi praktiki organov vnutrennikh del): Dis. ... kand. yurid. nauk. — M., 2001.

6. $\quad$ Korenev A.P. Administrativnoe pravo Rossii. Ch.1. - M., 2002.

7. Malein N.S. Pravonarushenie: ponyatie, prichiny, otvetstvennost'. - M., 1985.

8. Mel'nikov V.A. Pravo litsa, privlekaemogo k administrativnoi otvetstvennosti, na zashchitu: Avtoref. dis. ... kand. yurid. nauk. - M., 1995.

9. Maslennikov M.Ya. Proizvodstvo po delam ob administrativnykh pravonarusheniyakh v organakh militsii. Tver', 1992.

10. Yakimov A.Yu. Status sub"ekta prava (teoreticheskie voprosy) // Gosudarstvo i pravo. — 2003. — № 4 .

11. Kurakin A.V. Kompetentsiya politsii $v$ sfere realizatsii zakonodatel'stva ob administrativnykh pravonarusheniyakh // NB: Administrativnoe pravo i praktika administrirovaniya. - 2013. - 4. - C. 28-48. DOI: 10.7256/2306-9945.2013.4.8841. URL: http://www.e-notabene.ru/al/article_8841.html

12. Kurakin A.V., Badulin A.D., Tregubova E.V. Administrativnaya otvetstvennost' za pravonarusheniya na rynke alkogolya i rol' politsii v ee realizatsii // NB: Administrativnoe pravo i praktika administrirovaniya. — 2013. 10. — C. 28-74. DOI: 10.7256/2306-9945.2013.10.10151. URL: http://www.e-notabene.ru/al/article_10151. html

13. Kostennikov M.V., Kurakin A.V., Tregubova E.V. Konstitutsionnoe pravo na provedenie mirnykh sobranii, mitingov, demonstratsii, shestvii i piketirovaniya i administrativnaya otvetstvennost' kak sredstvo ego obespecheniya // NB: Administrativnoe pravo i praktika administrirovaniya. - 2013. - 8. - C. 82-105. DOI: 10.7256/2306-9945.2013.8.9955. URL: http://www.e-notabene.ru/al/article_9955.html

14. Serov A.S. Administrativno-pravovoe polozhenie advokata v proizvodstve po delam ob administrativnykh pravonarusheniyakh // Politseiskaya deyatel'nost'. - 2013. - 5. - C. 307-311. D0I: 10.7256/22221964.2013.5.10220.

15. Serov A.S. Status sub"ekta prava i ego realizatsiya v proizvodstve po delam ob administrativnykh pravonarusheniyakh // Politseiskaya deyatel'nost'. - 2013. - 6. - C. 413-421. DOI: 10.7256/22221964.2013.6.10433.

16. Kostennikov M.V., Kurakin A.V., Tregubova E.V. Konstitutsionnoe pravo na provedenie mirnykh sobranii, mitingov, demonstratsii, shestvii i piketirovaniya i administrativnaya otvetstvennost' kak sredstvo ego obespecheniya // NB: Administrativnoe pravo i praktika administrirovaniya. - 2013. - 8. - C. 82-105. DOI: 10.7256/2306-9945.2013.8.9955. URL: http://www.e-notabene.ru/al/article_9955.html

17. Tregubova E.V. Dozvolenie i zapret v administrativnom prave // NB: Administrativnoe pravo i praktika administrirovaniya. - 2013. - 8. - C. 25 - 56. DOI: 10.7256/2306-9945.2013.8.9953. URL: http://www.enotabene.ru/al/article_9953.html

18. E.V. Tregubova Zapreshchayushchie normy administrativnogo prava. // Administrativnoe i munitsipal'noe pravo. $-2011 .-1 .-$ C. $52-55$. 